\title{
Mobile Health for Elderly in India
}

\author{
Shilpa Srivastava \\ UTU, \\ Dehradun, India
}

\author{
Namrata Agrawal, PhD \\ NIFM, Faridabad \\ India
}

\begin{abstract}
The use of Information Communication Technology tools and methods in the healthcare sector is one of the most rapidly evolving areas today. India is a vast country consisting of 28 states and seven union territories. Health is the primary responsibility of each state and there is paucity of infrastructure and dearth of doctors in rural areas. The paper discusses the challenges and opportunities for the successful deployment of health services. Later we provide analysis that providing services through mobile to the elder population is the one of the most effective way.
\end{abstract}

\section{Keywords}

Information and communication technology, elder population, healthcare sector.

\section{INTRODUCTION}

Advancement in Information and communication technology has made the healthcare information and services globally accessible. The pressure on healthcare delivery systems is enormous in the developing and densely populated countries, so an efficient and cost effective strategy is the need of an hour. Information systems and web technologies have changed quality of services and people's life style. Advances in communication systems have impacted all aspects of our daily life and the field of health care is no exception. The use of Information Communication Technology in the health sector is one of the most rapidly growing areas in health care today [1]. The advancement in computer and communication technology have made the healthcare information and services globally accessible. Although, e-health services have reached to most of the segments but there are still some sections where more emphasis should be given specially in the developing nations. For eg:

$\begin{array}{ll}\text { - } & \text { Elderly and disabled } \\ \text { - } & \text { Career Women } \\ \text { - } & \text { Maternity and Child Care } \\ & \text { Adolescents }\end{array}$

Section 2 will discuss the ehealth projects in the Indian scenario and suggestions for providing comfortable health services for the elderly through the proper use of technology. Section 4 suggests the use of mobile for providing easy and comfortable health services to the elder generation. section 5 ends with a conclusion and the future scope.

\section{E-HEALTH IN INDIA}

India pioneered first telemedicine connectivity in rural areas by connecting the village Aragonda through satellite connection in the year 2000. This was first of its kind in the world. The gap is not so much in terms of technical knowledge and actual infrastructure. India has potential and necessary expertise required to implement e-health projects.

\subsection{Telemedicine Initiatives}

Telemedicine involves the Satellite communication along with information and communication technology to deliver the health care services more efficiently to the remote, distant and underserved regions of the country. The first telemedicine project was established by the Apollo group of hospitals in a village Aragonda in Andhra Pradesh in the year 2000. Since then it has shown a remarkable growth. Earlier it had few web cameras and ISDN telephone lines but now it is very well equipped with audio- video conferencing system and very small aperture terminal managed by ISRO(Indian Space Research Organization). In India the telemedicine program is mainly supported by:-

- Department of Information Technology (DIT)

- Indian Space Research Organization

- NEC Telemedicine program for North-Eastern states

- Apollo Hospitals

- Asia Heart Foundation

- State governments

Besides government organization telemedicine activities are also supported by the major private organizations. The CDAC(Center for Development of Advanced Computing) has developed the telemedicine software supporting various important activities in the medical domain like telecardiology, tele-ophthalmology etc. The technologies being used in this is generally ISDN, VSAT, and POTS. Through this the hospital at remote can easily be connected to the major hospitals (super specialty) like AIIMS, Apollo, SGPGIMS etc. The main objective of telemedicine programme is to serve the rural and remote areas by connecting the local hospitals to the more well equipped hospitals of the cities. In India telemedicine facilities is spreading very rapidly. They are managed in the rural hospitals of the states, in the union territories, as well as in Jammu \& Kashmir, Andaman \& Nicobar Islands, northern states etc[2]. The State level telemedicine activities are managed in the states like Kerala, Karnataka, Orissa, Chhattisgarh, Rajasthan, Andhra Pradesh, Punjab, West Bengal, Maharashtra etc. It has been estimated that every year around 1.5 lakh patients are taking advantage of health services through telemedicine every year[3]. In India Apollo Telemedicine Networking Foundation (ATNF), a part of Apollo Hospitals Group has evolved as the single largest provider. It is having about 125 peripheral centers, out of which 10 are located in overseas. ATNF is the pioneer in establishing its first telemedicine center in South Asia.[4]

\section{TECHNICAL GROWTH OF E- HEALTH IN INDIA}

Technology plays a major role in the in development and evolution of all sectors of our civilization. It has always been intertwined with human development for even every small economic or social growth. The implementation of ICT in the 
health sector, popularly known as e-health, is emerging as one of the most rapidly growing areas in health care today. We discuss the role of different technologies-Satellite, Mobile and cloud, in the successful deployment of e-health services.Table1 summarizes the description of the different projects and the technology used.

\section{MOBILE HEALTH FOR}

The study focuses on providing comfortable health services to the elderly people. According to [7]the need of an hour is to find an effective strategy to address the health conditions or problems faced by the elderly society. The growing burden of chronic diseases is affecting the life of older people greatly. The people all over the world are living longer life, and the rising levels of health problems are one of the major global challenges in todays environment. It has been estimated that the number of people in the age group of 60 will outnumber the children of having age group less than 5 by 2020 . This will be first time in the history and by 2050 , the population of persons over 60 years will be around 2 billion which is 841 million more than todays population. The main reasons of ageing is decreased mortality and declining fertility [8].

\subsection{Mobile Communication}

Mobile communication is a wireless form of communication in which voice and data can be transmitted and received through microwaves. The exchange of data can be done while moving from place to place. For eg: cellular, cordless, pagers etc.

In the recent years Mobile devices can be effectively used in providing medical support to the patients locating at a distant places. Services through mobile phones may include collection of community and clinical healthcare data, delivery of healthcare information to practitioners, real-time monitoring of patient vital signs etc.

The use of mobile phone is exploding across the developing world. According to the International Telecommunication Union (May2014) 95.5 percent of the overall world population are active mobile subscribers which is around 7 billion users. The m-health applications using mobile phones are mostly appropriate for data collection, analysis and registration \& monitoring patients. InfoLogic [Oladosu et al., 2009] announced on 13 October the first successful deployment of a mobile wireless application for health care industry in USA[9].

The integration of Mobile phones makes the services more efficient in terms of time and cost. Smartphone are major extensions on normal cell phones. They are the catalyst in the transition of health services to mobile devices [10].Few points which are responsible for the wide acceptance of mobile services are listed below.

- Mobiles are the lowest cost communication medium that can be used for e-health purposes.

- Mobiles are very easy to use by a common man, which is another reason for its popularity.

- Use of mobile technology does not require any urgent infrastructure.

- It can be used at any time and any place implying a high medical care $24 * 7$.

Considering these issues we can analyze mobile can be an effective, affordable and comfortable technology for providing health services to the elderly population. Now a days in the developing nations like India the use of mobile phone is increasing day by day. The elderly population can easily use and get connected to the doctor. In India we have "Practo" web services which can be accessible from the mobile are very beneficial and effective . The user can easily book an appointment and contact the pharmacist.

\section{CONCLUSION}

The study focuses the different technologies- like satellite, Internet, Mobile and Cloud being used in the successful deployment of e-health services in India. Providing comfortable services to the elderly population is one of the major challenges. We then throw light on the current scenario of elderly population and their unmet need of health facilities. Later on we suggest the use of mobile services for imparting comfortable health services to the elderly. In future we can build mobile apps specifically for the elderly population.

Table 1 E-health initiatives in India.

\begin{tabular}{|c|c|c|c|}
\hline S.No. & Project & Description & Technology \\
\hline 1. & Telemedicine & $\begin{array}{c}\text { Under the government initiative programme called } \\
\text { GRAMSAT(rural satellite) in 2001 ISRO started this network } \\
\text { through Indian Satellite System (INSAT). It is having around } \\
\text { 315 hospitals till date. [5]. }\end{array}$ & Satellite \\
\hline 2. & $\begin{array}{c}\text { Cloud Enabled } \\
\text { E-health Center }\end{array}$ & $\begin{array}{c}\text { This e-health center is considered as India's first fully } \\
\text { integrated e-health center based on cloud computing. It was } \\
\text { established in 2012 at Chausala village in Haryana Kaithal } \\
\text { District The main purpose is to provide health services at } \\
\text { remote areas at affordable price. }\end{array}$ & Cloud \\
\hline 3. & $\begin{array}{c}\text { Alcohol Web } \\
\text { India }\end{array}$ & $\begin{array}{c}\text { An e-health portal on alcohol use was developed by National } \\
\text { Drug Dependence Treatment Centre(NDDTC) New Delhi as } \\
\text { part of an initiative by the WHO, Geneva. The aim of this e- } \\
\text { health portal is to address the problem of alcohol use. }\end{array}$ & Internet \\
\hline 4. & $\begin{array}{c}\text { RFID Individual } \\
\text { Tracking and } \\
\text { Records } \\
\text { Management }\end{array}$ & $\begin{array}{c}\text { last year and recently expanded to a larger pilot in } \\
\text { Ahmedabad, India. IEEE launched this project successfully } \\
\text { in Ahmedabad. RFID-ITRM technology is central to } \\
\text { preventing medical errors, identifying victims of natural } \\
\text { disasters, and tracking and monitoring diseases and outbreaks, }\end{array}$ & Smart card \\
\hline
\end{tabular}




\begin{tabular}{|c|c|c|c|}
\hline & & $\begin{array}{c}\text { as well as infants and vaccination history. An electronic } \\
\text { medical record system is installed in a local community health } \\
\text { care center. The system is managed by local NGO Manav } \\
\text { Sadhna[6]. }\end{array}$ & \\
\hline 5. & $\begin{array}{c}\text { E-health Project } \\
\text { at Punjab }\end{array}$ & $\begin{array}{l}\text { An e-health clinic was established in Punjab in Malwa region. } \\
\text { A Hyderabad based NGO Naandi Foundation played a major } \\
\text { role in launching this project. This e-health clinic offers wide } \\
\text { range of medical services for chronic disease like cancer apart } \\
\text { from specialized health care services. }\end{array}$ & $\begin{array}{l}\text { Satellite and broad } \\
\text { band electronics } \\
\text { methodology. }\end{array}$ \\
\hline 6. & $\begin{array}{l}\text { Online Open } \\
\text { Access } \\
\text { Bibliography: } \\
\text { eLearning in the } \\
\text { Health Sector }\end{array}$ & $\begin{array}{l}\text { To collect the informational needs of the medical } \\
\text { group/association of India the two government agencies } \\
\text { ICMR(Indian Council of Medical Research) and the } \\
\text { NIC(National Informatics Center) has established } \\
\text { MEDLARS( Medical Literature Analysis and Retrieval } \\
\text { System . this will help to medical professional to gain } \\
\text { information in this domain. }\end{array}$ & Internet \\
\hline 7. & $\begin{array}{l}\text { Collaborative } \\
\text { Knowledge } \\
\text { Sharing } \\
\text { through } \\
\text { Telemedicine } \\
\text { Network: }\end{array}$ & $\begin{array}{l}\text { The sharing of the various academic activities of the premier } \\
\text { medical institutions like AIIMS, PGIMER, SGPGIMS, } \\
\text { Christian Medical College, Vellore is being done through the } \\
\text { telemedicine. }\end{array}$ & Satellite \\
\hline 8. & $\begin{array}{l}\text { e-Continuing } \\
\text { Medical } \\
\text { Education (e- } \\
\text { CME) }\end{array}$ & $\begin{array}{l}\text { To enhance the Continuing Medical education programme the } \\
\text { ministry of Health and family Welfare is planning to connect } \\
\text { all the major government medical college with high } \\
\text { bandwidth fiber for the fast and efficient information sharing. }\end{array}$ & Internet \\
\hline 9. & $\begin{array}{l}\text { National } \\
\text { OncoNET } \\
\text { Project }\end{array}$ & $\begin{array}{c}\text { The main purpose of this project is to connect the regional } \\
\text { cancer centers to the peripheral centers located in major cities } \\
\text { for the timely detection and treatment or the rehabilitation of } \\
\text { the cancer patients. }\end{array}$ & Satellite/Internet \\
\hline 10. & $\begin{array}{l}\text { National Digital } \\
\text { Medical Library } \\
\text { Consortium }\end{array}$ & $\begin{array}{l}\text { In order to develop the medical information resources } \\
\text { electronically the DGHS(Director General of Health Services) } \\
\text { took the initiative of building the National Medical Library } \\
\text { Electronic Resources in Medicine (ERMED). }\end{array}$ & Internet \\
\hline 11. & $\begin{array}{l}\text { SAARC } \\
\text { Telemedicine } \\
\text { Network }\end{array}$ & $\begin{array}{l}\text { The government of India has taken initiative in providing } \\
\text { health care services to the countries who are members of } \\
\text { SAARC. The main purpose is to provide specialist healthcare } \\
\text { facilities and sharing of medical expertise and knowledge to } \\
\text { the SAARC countries. }\end{array}$ & Satellite \\
\hline 12. & $\begin{array}{l}\text { Pan- } \\
\text { African } \\
\text { eNetwork } \\
\text { Project }\end{array}$ & $\begin{array}{l}\text { This project aims in promoting the tele-education in the field } \\
\text { of medical between India and Pan African. It connects } 53 \\
\text { member states of the union through satellite and fiber optic. }\end{array}$ & Satellite/Internet \\
\hline 13. & eHealth-Care & $\begin{array}{l}\text { This is a web based programme that keeps track of the } \\
\text { patients' health record. }\end{array}$ & Internet \\
\hline 14. & WHP & $\begin{array}{l}\text { This is a not-for - profit organization that delivers health } \\
\text { services to the remote areas in the country. It uses social } \\
\text { franchising to connect to the villages through technology for } \\
\text { providing high level of care and medical treatment.to the rural } \\
\text { communities. }\end{array}$ & Internet \\
\hline 15. & IDSP & $\begin{array}{l}\text { With the support of World Bank the programme Integrated } \\
\text { Disease Surveillance Programme (IDSP) was started in } \\
\text { November 2004. The main purpose was to detect and respond } \\
\text { the disease at the initial stage. }\end{array}$ & Telephone \\
\hline 16. & $\begin{array}{l}108 \text { medical } \\
\text { emergency } \\
\text { services }\end{array}$ & $\begin{array}{l}\text { This service is based on a single toll free number 1-0-8 which } \\
\text { can be called at any time during any emergency medical } \\
\text { condition. It ensures a prompt communication and an active } \\
\text { response. At first the type of emergency is assessed, the } \\
\text { ambulances are send along with the well trained emergency } \\
\text { medical technicians to provide medical treatment well on } \\
\text { time. Later on the patient is transferred to the suitable health } \\
\text { care hospital. }\end{array}$ & Mobile \\
\hline 17. & $\begin{array}{l}\text { India online } \\
\text { health.com }\end{array}$ & $\begin{array}{l}\text { It is a web based platform for providing services to the } \\
\text { patients suffering from the chronic diseases and ensures better } \\
\text { management and transparency in healthcare system in Indian }\end{array}$ & Internet \\
\hline
\end{tabular}




\section{REFERENCES}

[1] Dong Min, Byong Woo Lee, Sung Won Yoon, Cheol OhPark,"Actual condition of Korean e-Health: What do enterprisers want for developing e-Health Industry?" 9th International Conference on e-Health Networking, Application and Services, Taipei, pp304-307,(2007).

[2] Bedi BS. Telemedicine in India: Initiatives and Perspective, e-health 2003: Addressing the Digital Divide. (2003)

[3] http://www.isro.org/scripts/telemedicine.aspx

[4] http://www.telemedicineindia.com/

[5] S K Mishra, Deepak Gupta, Jagdish Kaur, "Telemedicine in India: Initiatives and vision", 9th International Conference on E-health Networking Applications and services, Taipei, pp.81-83, (2007).

[6] http://sites.ieee.org/societies/2012/05/09/, 2012.
[7] Ageing well" must be a global priority[source:http://www.who.int/mediacentre/news/rel eases/2014/lancet-ageing-series/en/]

[8] World Population Ageing 2013, http://www.un.org/en/development/desa/population/publi cations/pdf/ageing/WorldPopulationAgeing2013.pdf.

[9] Odalsu. John B, Emuoyinbofarhe, Justice O, Ojo, Sunday O, Adigun, Mathew O. Framework for a Context -Aware Mobile E-Health Service Discovery Discovery Infrastructure for Rural / Suburban Healthcare. Journal of Theoretical and Applied Information Technology,1(1):pp.081-091.

[10] Shilpa Srivastava,Millie Pant,Ajith Abraham,Namrata Agrawal. Technological Growth of Ehealth Services.Computational and Mathematical Models in Medicine. Volume 2015, Article ID 894171, 18 pages .http://dx.doi.org/10.1155/2015/894171 